\title{
Manufacturing of $\alpha$-lactalbumin-enriched whey systems by selective thermal treatment in combination with membrane processes
}

\author{
Christian KIESNER $^{\text {a* }}$, Ingrid CLAWIN-RÄDECKER ${ }^{\mathrm{b}}$, Hans MEISEL $^{\mathrm{b}}$, \\ Wolfgang BUCHHEIM ${ }^{\mathrm{a}}$ \\ a Department of Process Engineering, Federal Dairy Research Centre, Kiel, Germany \\ ${ }^{\mathrm{b}}$ Department of Chemistry and Physics, Federal Dairy Research Centre, Kiel, Germany
}

\begin{abstract}
Till now, industrial fractionation and isolation processes for whey proteins have mainly been based on chemical process steps combined with membrane techniques. Actually, the reaction kinetics of thermal denaturation of $\alpha$-lactalbumin and $\beta$-lactoglobulin allow to compute the remaining portions of native whey proteins in dependence of the selected temperature-time conditions. In the temperature range of $85-95{ }^{\circ} \mathrm{C}$ and corresponding holding times, the differences in reaction rates for both whey protein fractions are highest i.e. only moderate denaturation for $\alpha$-lactalbumin but extensive denaturation for $\beta$-lactoglobulin. After such thermal treatment the ratio of native $\alpha$-lactalbumin to native $\beta$-lactoglobulin may increase from 0.3 (raw milk) to approximately 4 . An effective separation of aggregated (denatured) whey proteins from soluble whey proteins is achieved by means of microfiltration (ceramic membranes / $0.1 \mu \mathrm{m}$ ).
\end{abstract}

$\alpha$-lactalbumin / thermal treatment / membrane processes

\section{INTRODUCTION}

Several processes have been proposed to separate the major whey proteins of bovine milk, i.e. $\beta$-lactoglobulin ( $\beta$-LG) and $\alpha$-lactalbumin $(\alpha$-LA) or at least to produce whey systems with $\alpha$-LA being strongly enriched as compared to $\beta$-LG $[1,3,7-10,12,13]$. Major reasons for these various attempts are not only to achieve whey protein concen-

\footnotetext{
* Correspondence and reprints. kiesner@bafm.de
}

trates or isolates with attractive functional properties [1, 12, 13] but to produce protein systems having an appropriate composition for being used in infant formulas [3, 6-8]. In the present paper a further possibility for obtaining bovine whey systems with a modified, i.e. high relative $\alpha$-LA content, is described which is primarily based on the different denaturation kinetics of $\alpha$-LA and $\beta$-LG. 


\section{PROCESS DESCRIPTION}

$\alpha$-LA-enriched whey systems are obtained by a two-step process. At first, a high portion of $\beta-\mathrm{LG}$ is denatured by a defined thermal treatment leaving a substantial portion of $\alpha$-LA in its native state. In a second step, the remaining soluble portions of the whey proteins are separated from the aggregated portions by means of microfiltration (MF).

\subsection{Thermal treatment and defining of the heating conditions}

In a temperature range from $70{ }^{\circ} \mathrm{C}$ to $150{ }^{\circ} \mathrm{C}, \beta-\mathrm{LG}$ variants $\mathrm{A}$ and $\mathrm{B}$ as well as $\alpha$-LA undergo different degrees of denaturation. The reaction kinetics have been described by Dannenberg [4]. The change of the temperature-dependent reaction rate constant $k$ (Fig. 1) shows that the activation energies required for the denaturation of the individual whey proteins depend on the tem- perature range. Whereas the reaction rate constants are similar for the three whey proteins up to a temperature of $80^{\circ} \mathrm{C}$, for temperatures above $80^{\circ} \mathrm{C}$ the reaction rate constants of the denaturation of $\alpha$-LA are far below those of $\beta$-LG A and $B$, the latter being highest at approximately $91{ }^{\circ} \mathrm{C}$. In the temperature range above $80^{\circ} \mathrm{C}(\alpha$-LA) or $91{ }^{\circ} \mathrm{C}(\beta-\mathrm{LG})$ the activation energies are by a factor of four lower than at temperatures below $80{ }^{\circ} \mathrm{C} / 91{ }^{\circ} \mathrm{C}$, thus explaining the flat curve of the function $\ln k=f(1 / T)$. In correlation with the selected temperature range of the heat treatment, the reaction kinetics results in different denaturation rates of individual whey proteins. Taking into account the reaction orders found by Dannenberg [4] and the corresponding activation energies, the remaining portions of native whey proteins after a heat treatment can be computed by the following equations:

(I) For the denaturation of $\alpha$-LA, the remaining (soluble) portion of $C_{(\tau) \alpha-\mathrm{LA}}$ after a reaction time $\tau$ (holding time) at a

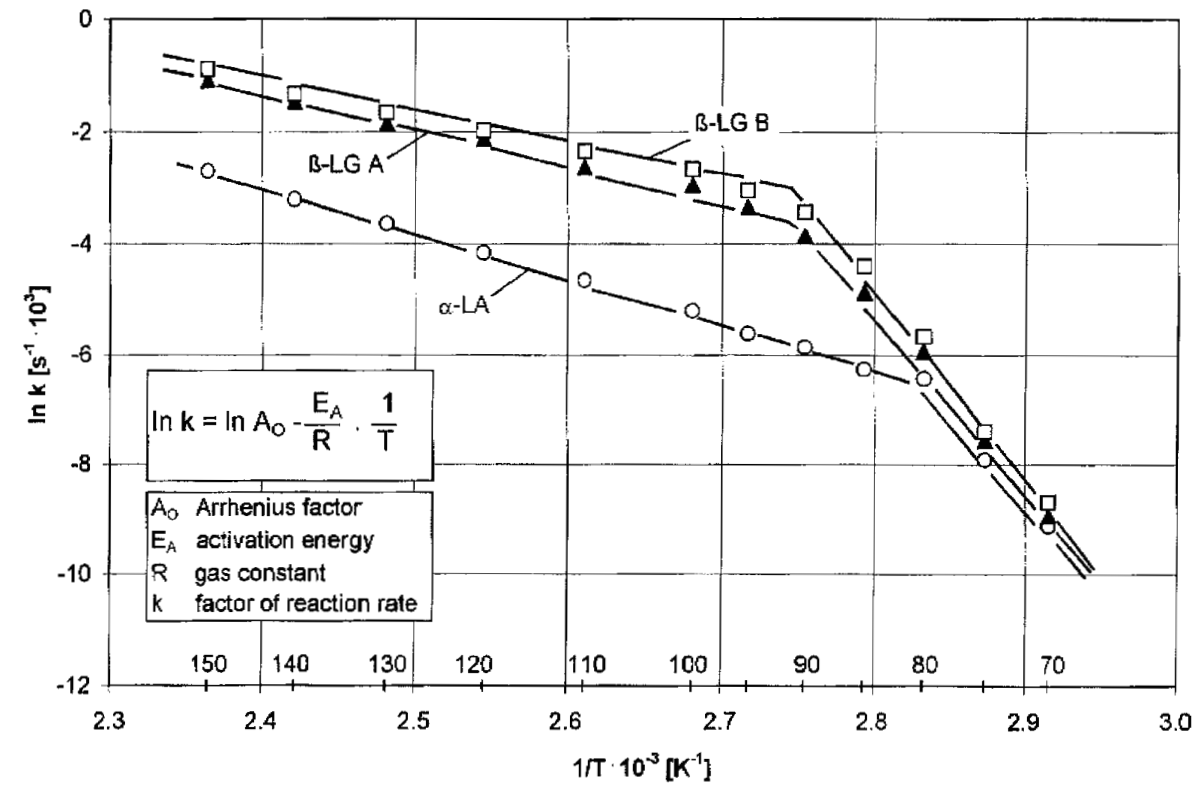

Figure 1. Arrhenius-Plot for denaturation of whey proteins according to Dannenberg [4] $\operatorname{In} k=f(1 / T)$. 
heating temperature $T$ in $(\mathrm{K})$ is:

$$
\begin{aligned}
C_{(\tau) \alpha-\mathrm{LA}}= & C_{0 \alpha-\mathrm{LA}} \exp \left(-\mathrm{A}_{\alpha-\mathrm{LA}} \tau\right. \\
& \left.\times \exp \left(-\mathrm{E}_{\mathrm{a} \alpha-\mathrm{LA}} / \mathrm{RT}\right)\right) .
\end{aligned}
$$

(II) For the denaturation of $\beta-\mathrm{LG} A, B$ the correlation is as follows:

$C_{(\tau) \beta-\mathrm{LG} \mathrm{A}, \mathrm{B}}=C_{0 \beta-\mathrm{LG} \mathrm{A,B}}\left(1+0.5 \mathrm{~A}_{\beta-\mathrm{LG} \mathrm{A}, \mathrm{B}} \tau\right.$ $\left.\times \exp \left(-\mathrm{E}_{\mathrm{a} \beta-\mathrm{LG} \mathrm{A,B}} / \mathrm{RT}\right)\right)^{-2}$. (2)

$C_{0 \alpha-\mathrm{LA}}, C_{0 \beta \text {-LG A,B }}$ are the corresponding initial concentrations of $\alpha$-LA and of $\beta$-LG $\mathrm{A}, \mathrm{B}$ in $\left[\mathrm{mg} \cdot \mathrm{kg}^{-1}\right]$ and $R$ the gas constant $\left(R=8.314\left[\mathrm{~J} \cdot \mathrm{mol}^{-1} \cdot \mathrm{K}^{-1}\right]\right)$. The detected Arrhenius factors $\mathrm{A}$ and activation energies $\mathrm{E}_{\mathrm{a}}$ in the temperature range between $70^{\circ} \mathrm{C}$ and $150{ }^{\circ} \mathrm{C}$ are listed in Table I.

Industrially applied indirect heating processes have revealed that the temperature/time depending denaturation and thus also the remaining contents of undenatured whey proteins are not only determined by the holding time at constant heating temperature but also the corresponding heating-up and cooling phases. Based on the reaction kinetics data of Dannenberg, Biewendt [2] has derived equations for computing the undenatured portions of whey proteins remaining after a real heat treatment by using sterilization values ( $F$-values).
For the remaining content $(R C)$ of $\alpha$-LA the relationship is:

$R C_{\alpha-\mathrm{LA}}=C_{0 \alpha-\mathrm{LA}} \exp \left(-0.00177 F_{\alpha-\mathrm{LA}}\right) .(3)$

$F_{\alpha-\mathrm{LA}}$ is corresponding to the respective $F$-value $\left(F=\int 10^{(\vartheta(\tau)-\vartheta \mathrm{B}) / \mathrm{z}} \mathrm{d} \tau\right.$ and $\vartheta(\tau)$ the real temperature-time-curve of the heat treatment) for the denaturation of $\alpha$-lactalbumin with $z$-value of $9{ }^{\circ} \mathrm{C}$ for temperatures below $80{ }^{\circ} \mathrm{C}$ and a $z$-value of $43{ }^{\circ} \mathrm{C}$ for temperatures above $80{ }^{\circ} \mathrm{C}$ at a reference temperature $\vartheta_{\mathrm{B}}$ of $80{ }^{\circ} \mathrm{C}\left(z=9^{\circ} \mathrm{C}\right.$ for $\vartheta(\tau)<80^{\circ} \mathrm{C}$ and $z=43{ }^{\circ} \mathrm{C}$ for $\vartheta(\tau)>80^{\circ} \mathrm{C}$ at $\vartheta_{\mathrm{B}}=80^{\circ} \mathrm{C}$ ).

In analogy, the remaining content of $\beta$-LG $\mathrm{A}$ is

$R C_{\beta-\mathrm{LG} \mathrm{A}}=C_{0 \beta-\mathrm{LG} \mathrm{A}}\left(1+0.017 F_{\beta-\mathrm{LG} \mathrm{A}}\right)^{-2}$

$\left(F_{\beta \text {-LG A }}\right.$ is calculated with $z=9{ }^{\circ} \mathrm{C}$ for $\vartheta$ $(\tau)<91{ }^{\circ} \mathrm{C}$ and $z=55^{\circ} \mathrm{C}$ for $\vartheta(\tau)>91^{\circ} \mathrm{C}$ at $\left.\vartheta_{\mathrm{B}}=91^{\circ} \mathrm{C}\right)$.

For $\beta$-LG B the equation is:

$R C_{\beta-\mathrm{LG} \mathrm{B}}=C_{0 \beta-\mathrm{LG} \mathrm{B}}\left(1+0.0235 F_{\beta-\mathrm{LG} \mathrm{B}}\right)^{-2}$

$\left(F_{\beta \text {-LG B }}\right.$ is calculated with $z=8.5^{\circ} \mathrm{C}$ for $\vartheta(\tau)<91{ }^{\circ} \mathrm{C}$ and $z=61{ }^{\circ} \mathrm{C}$ for $\vartheta(\tau)>91{ }^{\circ} \mathrm{C}$ at $\left.\vartheta_{\mathrm{B}}=91{ }^{\circ} \mathrm{C}\right)$.

The equations $(3,4,5)$ allow to compute the remaining contents of the native whey proteins for any temperature-time curve by using the sterilization values ( $F$-values). In

Table I. Reaction kinetics data for the denaturation of $\beta$-LG A, $\beta$-LG B and $\alpha$-LA in skim milk

\begin{tabular}{|c|c|c|c|c|}
\hline Whey protein & Reaction order & Temp.-range & $\mathrm{E}_{\mathrm{a}}\left[\mathrm{kJ} \cdot \mathrm{mol}^{-1}\right]$ & $\mathrm{A}\left[\mathrm{s}^{-1}\right]$ \\
\hline$\alpha-\mathrm{LA}$ & 1 & $\begin{array}{l}70-80{ }^{\circ} \mathrm{C} \\
85-150{ }^{\circ} \mathrm{C}\end{array}$ & $\begin{array}{r}268.56 \\
69.01\end{array}$ & $\begin{array}{l}7.6 \times 10^{36} \\
2.3 \times 10^{7}\end{array}$ \\
\hline$\beta$-LG A & 1.5 & $\begin{array}{l}70-90^{\circ} \mathrm{C} \\
95-150{ }^{\circ} \mathrm{C}\end{array}$ & $\begin{array}{l}265.2 \\
54.07\end{array}$ & $\begin{array}{l}3.5 \times 10^{36} \\
1.8 \times 10^{6}\end{array}$ \\
\hline$\beta$-LG B & 1.5 & $\begin{array}{l}70-90^{\circ} \mathrm{C} \\
95-150{ }^{\circ} \mathrm{C}\end{array}$ & $\begin{array}{r}279.96 \\
47.75\end{array}$ & $\begin{array}{l}6.9 \times 10^{38} \\
3.1 \times 10^{5}\end{array}$ \\
\hline
\end{tabular}
according to Dannenberg [4]. 
heating ranges below the selected reference temperatures $\vartheta_{\mathrm{B}}$, the indicated smaller $\mathrm{z}$-values are used. The reference temperatures were selected in such a way that they corresponded to the respective transition temperature from high to lower activation energies [4].

For heat treatments with negligible heating and cooling phases (momentum heating) the remaining contents of the native whey proteins as well as the ratio $\alpha$-LA/ $\beta$-LG, depending on the maximum heating temperature (between $91{ }^{\circ} \mathrm{C}$ and $150{ }^{\circ} \mathrm{C}$ ) and on the respective holding time, were computed according to equations 3 to 5 . The results are given in Figure 2. The diagrams were established for the initial contents $\mathrm{C}_{0} \alpha$-LA $=1082 \mathrm{mg} \cdot \mathrm{L}^{-1}, \mathrm{C}_{0} \beta$-LG A $=$ $2130 \mathrm{mg} \cdot \mathrm{L}^{-1}$ and $\mathrm{C}_{0 \beta-\mathrm{LGB}}=1777 \mathrm{mg} \cdot \mathrm{L}^{-1}$.

It can be deduced from the curve of the ratio $\alpha$-LA / $(\beta-\mathrm{LG} A+\beta-\mathrm{LG}$ B) that by a defined heat treatment of milk (temperature-time-combination), the remaining contents of native $\alpha$-LA are higher than of $\beta$-LG $\mathrm{A}+\mathrm{B}$. This is true for all the temperatures in the range from $91{ }^{\circ} \mathrm{C}$ to $150{ }^{\circ} \mathrm{C}$, the ratio being, however, highest at $91{ }^{\circ} \mathrm{C}$. For the considered heating temperatures, the curves demonstrate maximum values at a certain holding time. Apart from a decreasing ratio $\alpha$-LA / $(\beta$-LG A $+\beta$-LG B) a further prolongation of the holding times will cause a more or less complete denaturation of all whey protein fractions (Fig. 2). For an optimal yield of soluble $\alpha$-LA, the temperaturetime-combinations of the heat treatment have to be selected in such a way that they can be allocated to the range of the increasing ratio $\alpha$-LA / $(\beta$-LGA $+\beta$-LGB $)$. This case is represented in Figure 3 as an example for a heating temperature of $91{ }^{\circ} \mathrm{C}$.

For heat treatments with heating and cooling phases, i.e. in all cases where indirect heating and cooling are used, the ratio of the native whey proteins $\alpha$-LA / ( $\beta$-LGA + $\beta$-LGB) can be computed by means of sterilization values with the equations (3-5) for the corresponding temperature-time curves.

\section{MATERIALS AND METHODS}

\subsection{Materials and experimental conditions}

Skim milk as well as sweet whey were used for manufacturing whey protein systems with higher relative $\alpha$-LA contents. The heat treatment was performed under continuous flow in plate heat exchangers and under discontinuous conditions in the vapour-heated double-walled stirred vessel. For the continuous heating, the temperature-time curves of the heat treatments were followed by temperature measuring and by computing the mean residence time in the heating, holding and cooling sections. For the discontinuous heat treatment in the stirred vessel the temperature of the product was continuously measured and registered. The heating conditions (maximum heating temperature and holding time) were roughly adjusted by means of the diagram shown in Figure 2 whereas the real denaturation of the whey proteins was determined by means of the registered temperature-time curves and computation of $F$-values.

The thermally pre-treated skim milk/ sweet whey was microfiltered at $50{ }^{\circ} \mathrm{C}$ by using a ceramic membrane with a pore size of $0.1 \mu \mathrm{m}$ (MFS-1, Tetra Pak Filtration Systems A/S, Aarhus/DK). The $85 \mathrm{~cm}$ long multi-chanel element (P 19-40) consisting of 19 channels of $4 \mathrm{~mm}$ diameter each, resulting in a total filtering surface of $0.2 \mathrm{~m}^{2}$. The membranes used (SCT-Mebralox, Bazet, France) are made up of a Zirconium oxide layer on an alumina support. In order to observe a more or less constant transmembrane pressure difference, the permeate was recirculated along the membrane (Fig. 4). At the inlet of the permeate into the membrane module, the pressure differences of $\mathrm{P} 1-\mathrm{P} 2=3.9-3.1=0.8$ bar for skim milk and $\mathrm{P} 1-\mathrm{P} 2=3.85-3.15=0.7$ bar for sweet whey were adjusted. Accordingly, the pressure differences at the outlet of the membrane module were at P4-P3 $=2-1.6=0.4$ bar for skim milk and sweet whey. The overflow 
retentate $(\mathrm{FICR})$ was at $350 \mathrm{~L} \cdot \mathrm{h}^{-1}$. When starting microfiltration, the permeate flux under the aforementioned adjustment was at approximately $19 \mathrm{~kg} \cdot \mathrm{h}^{-1}$ corresponding to a surface specific flux of $95 \mathrm{~kg} \cdot \mathrm{h}^{-1} \cdot \mathrm{m}^{-2}$. These operating conditions were applied in all the performed tests. Figure 4 demonstrates the complete course of procedure as used for the manufacture of $\alpha$-LA enriched whey protein systems on a laboratory scale. The maximum operating time for microfiltration was at approximately $1.5 \mathrm{~h}$.
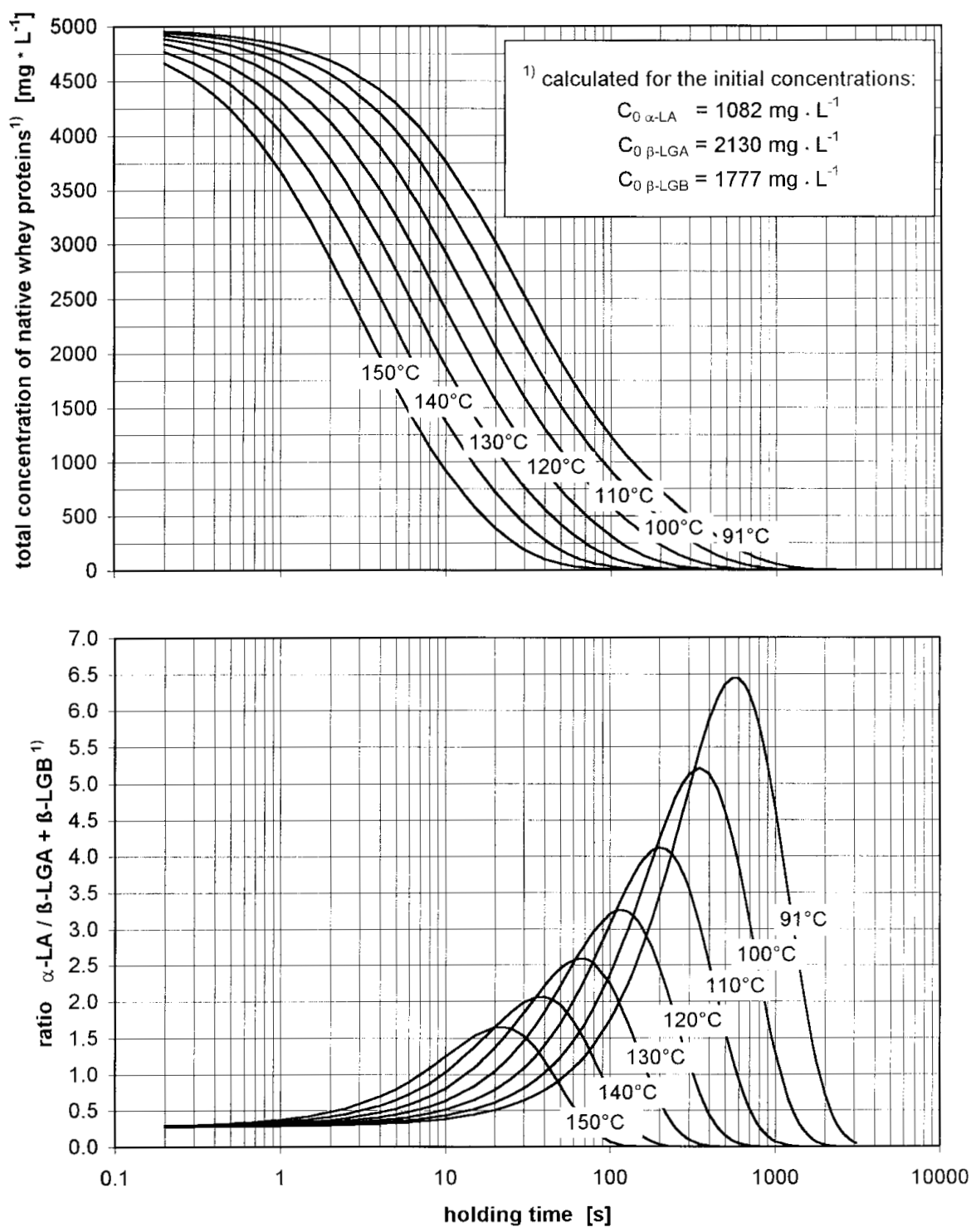

Figure 2. Correlations of remaining contents of whey proteins and the ratio $\alpha-\mathrm{LA} / \beta-\mathrm{LG} \mathrm{A}+\mathrm{B}$ for different heating temperatures $\left(91{ }^{\circ} \mathrm{C}-150{ }^{\circ} \mathrm{C}\right)$ and holding times. 


\subsection{Analytical methods}

For assessing thermal denaturation and separating of native from denatured whey proteins during microfiltration, the concen- trations of whey proteins were determined analytically both in the initial product, after thermal treatment, and in the MF permeate and retentate. The methodical provision according to German Industrial Standard

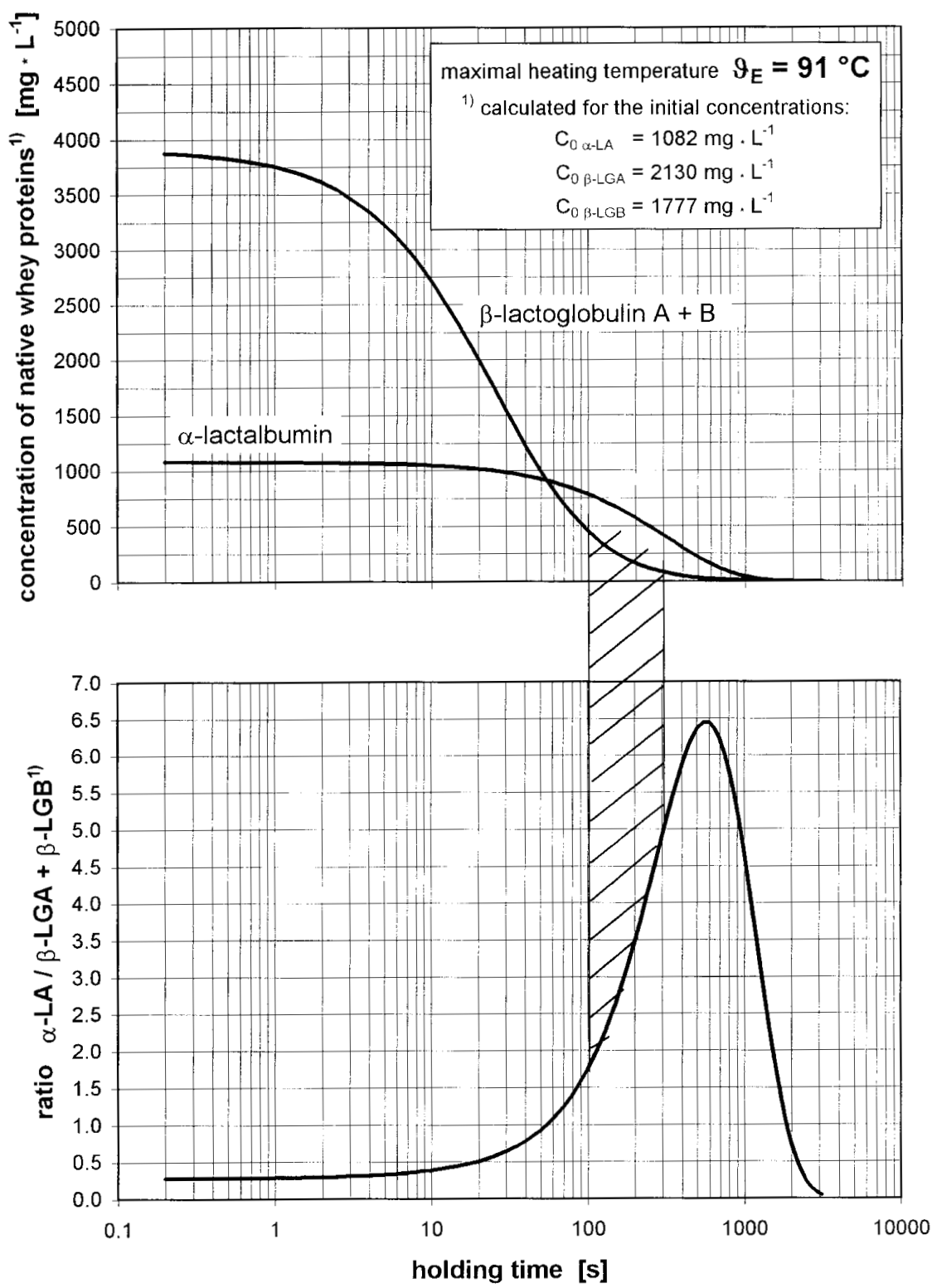

Figure 3. Pattern of remaining contents of $\alpha$-LA and $\beta-L G A+B$ at a heating temperature of $91^{\circ} \mathrm{C}$ in dependency on the holding time. 


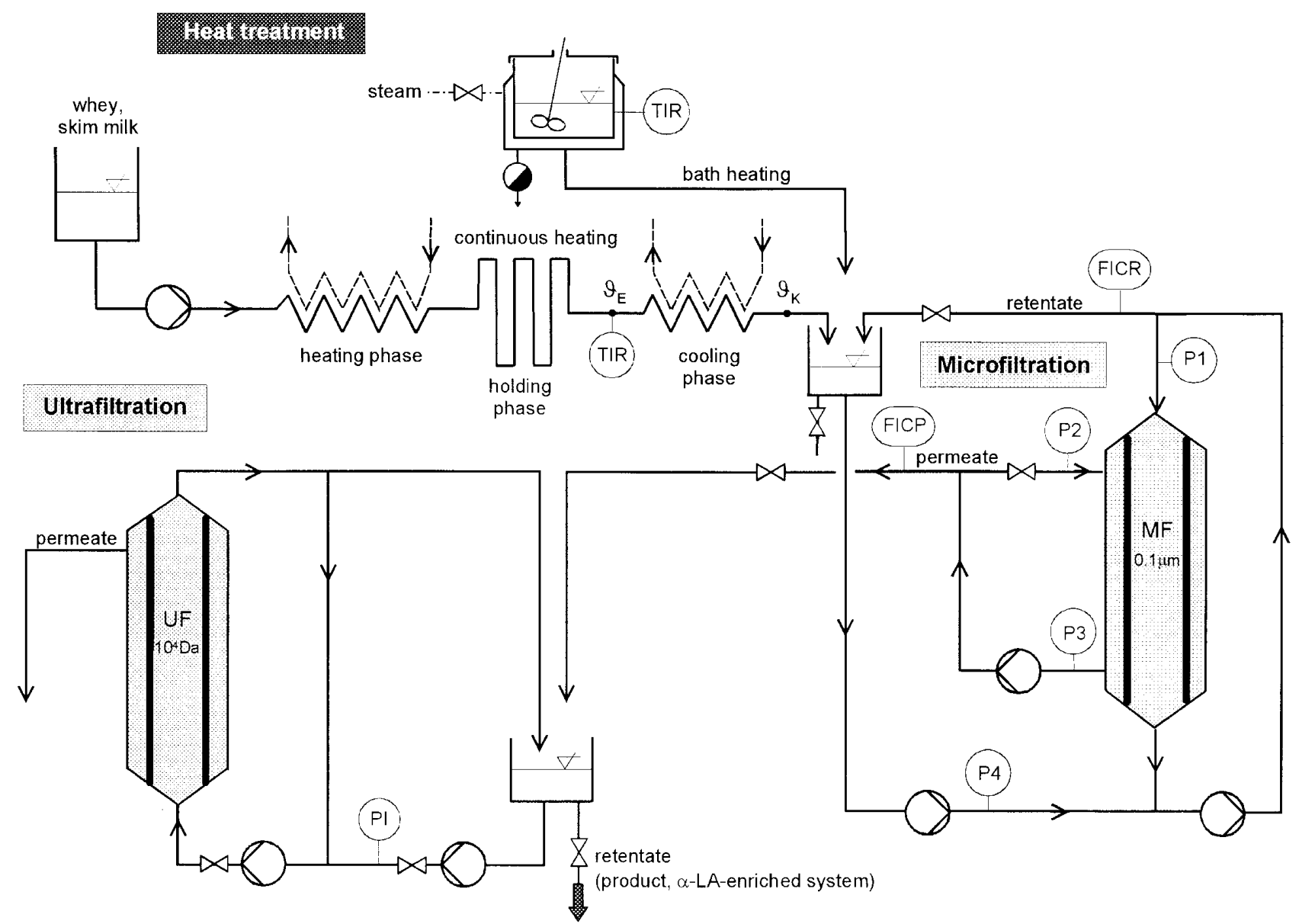

Figure 4. Course of procedure at the manufacture of $\alpha$-LA enriched concentrates. 
(DIN 10473) was used for determining the acid soluble whey proteins, meaning the determination of the contents of acid soluble $\beta$-lactoglobulin in heat-treated milk [5]. The analytical determination of the $\alpha$-lactalbumin concentration was performed similarly. The determination of acid soluble whey proteins is based on the isoelectric precipitation of casein and denatured whey protein from heat-treated milk at $\mathrm{pH}$ 4.6. The acid whey was separated by centrifugation and filtration (pore size $0.2 \mu \mathrm{m}$ ). The content of the soluble whey proteins was determined by reversed-phase HPLC. For quantification, a single-point calibration with a reference sample was used.

The tryptophan content and the protein content according to Kjeldahl served as further parameters. The tryptophan content was quantified using 4th derivative spectroscopy [11]. The determination was based on the UV absorption of tryptophan which shows a characteristic trough at $294 \mathrm{~nm}$ in the 4th derivative spectrum. The amplitude of the 4 th derivative $\left(\delta^{4} \mathrm{~A} / \delta \lambda^{4}\right)$ of the trough at $294 \mathrm{~nm}$ increased proportionally with increasing tryptophan concentration. For calibration, $\mathrm{N}$-acetyl-L-tryptophan ethylester (Sigma) was used; the calibration curve was linear $(r \geq 0.999)$ in the range from 2 to $200 \mathrm{nmol} \cdot \mathrm{mL}^{-1}$. All samples $(15-55 \mathrm{mg}$ ) were diluted with $10 \mathrm{~mL}$ of $6 \mathrm{~mol} \cdot \mathrm{L}^{-1}$ guanidine- $\mathrm{HCl}$ buffer and filtered before measuring the UV spectrum.

\section{RESULTS AND DISCUSSION}

For the experiments with both skim milk and sweet whey the temperature-time conditions were chosen in such a way that they enabled a ratio of native $\alpha$-LA / $(\beta$-LGA + $\beta$-LGB) in the range of 0.7 to 10 .

The ratio of $\alpha$-LA / $(\beta$-LGA $+\beta$-LGB $)$, computed by means of equations (3-5), was compared to that of the analytically measured whey protein concentrations (Fig. 5). A relatively high concordance of

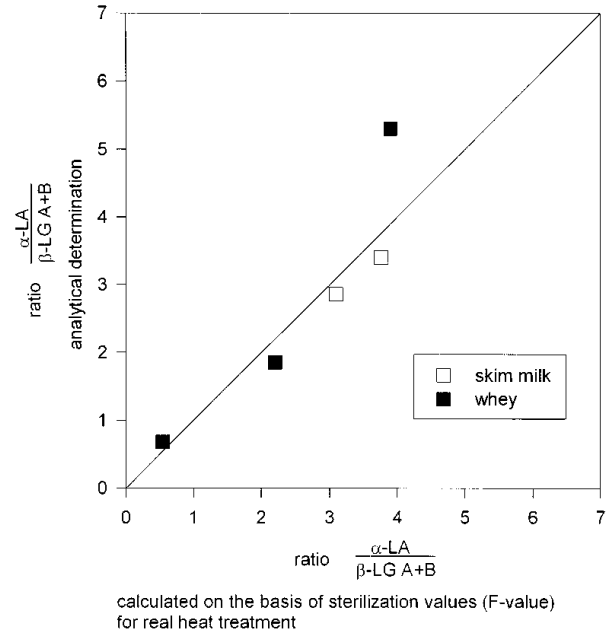

Figure 5. Comparison of ratio $\alpha-\mathrm{LA} / \beta-\mathrm{LG}$ $\mathrm{A}+\mathrm{B}$, computed according to equations (3-5), with analytically measured contents.

both values could be stated. Thus, the conditions for the heat treatment could be predetermined and the desired increase of soluble $\alpha$-LA versus $\beta$-LGA + B be adjusted accordingly. However, the computed remaining contents of whey proteins were generally lower than those determined analytically.

Figure 6 shows the permeate flux in function of the operating time of microfiltration with skim milk and sweet whey, respectively. As expected, the flux decrease was significantly higher with skim milk than with sweet whey.

For the manufacture of $\alpha$-LA-enriched whey systems from thermally treated skim milk or sweet whey the separating of native from denatured whey proteins by microfiltration is of decisive importance. For assessing the separation degree of microfiltration, the analysis of the material flux of analytically measured concentrations of native portions of the two whey proteins revealed to be of advantage. The material flux, based on the initial quantity of whey proteins in 


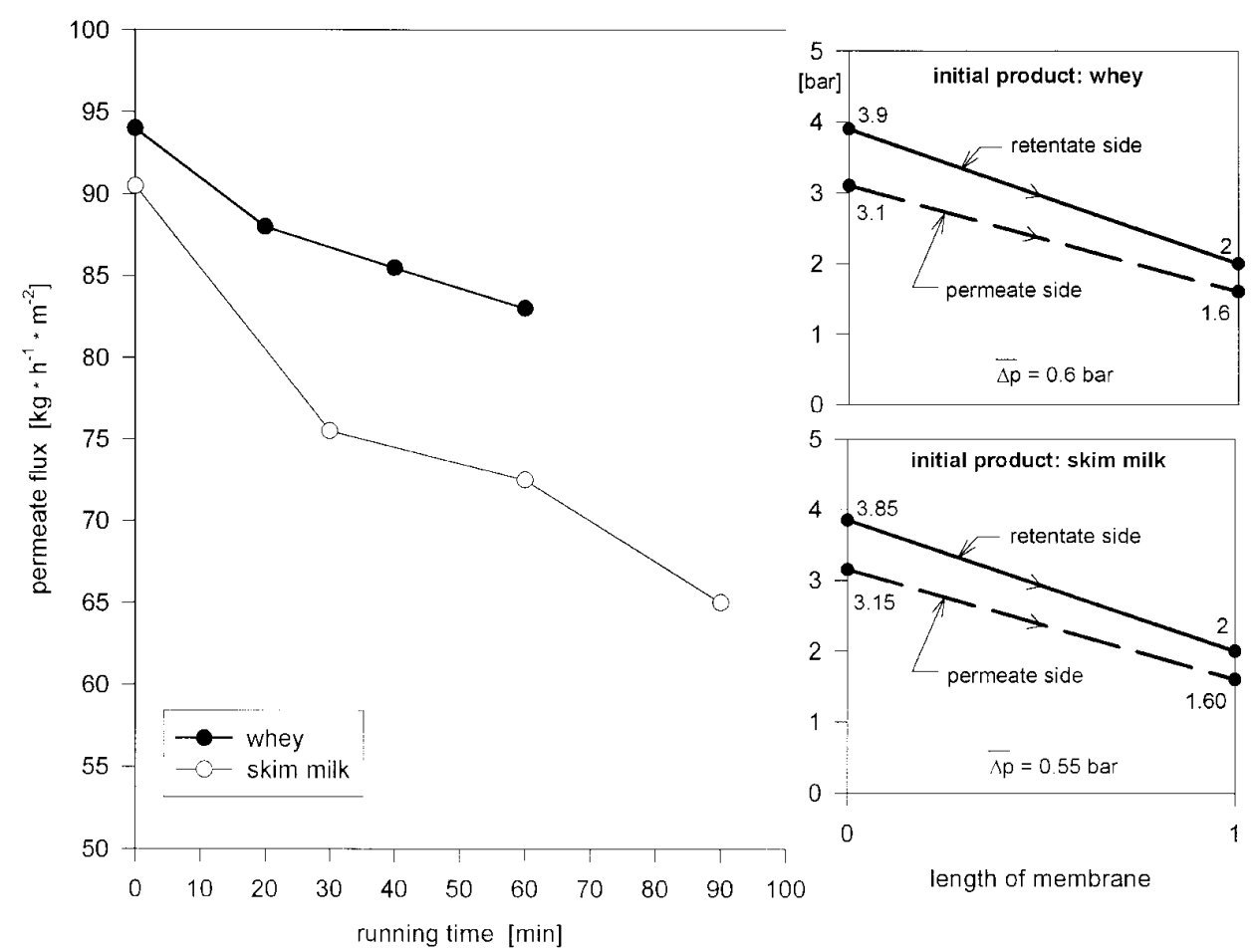

Figure 6. Permeate flux and running conditions of microfiltration.

untreated skim milk or sweet whey, was calculated after heat treatment in the MF permeate and retentate (Figs. 7 and 8).

Figure 7 shows the course of the material flux of native and denatured portions of both whey proteins for a selected test with skim milk. Due to the selected heat treatment $\left(\mathrm{F}_{\alpha-\mathrm{LA}}=1298 \mathrm{~s}, \mathrm{~F}_{\beta \text {-LGA }}=515.5 \mathrm{~s}\right.$ and $\mathrm{F}_{\beta-\mathrm{LGB}}=505.2 \mathrm{~s}$ ) approximately $16 \%$ of $\alpha$-LA and only $1.4 \%$ of $\beta-\mathrm{LG} A+B$ remained in the native state. The ratio of $\alpha$-LA / $(\beta$-LGA $+\beta$-LGB) increased from 0.26 in initial milk to approximately 3 in heat-treated milk. By microfiltration, 5.3\% of the initial quantity of native $\alpha$-LA were transferred into the permeate and $0.4 \%$ of $\beta$-LG A+B. As regards $\alpha$-LA, this corresponds to a separation degree of the microfiltration of $32 \%$ and a total yield of the whole process of $5.3 \%$.
A similar course of the material flux of both whey proteins was found at using sweet whey. The ratio $\alpha$-LA / $(\beta-\mathrm{LGA}+\beta$-LGB $)$ increased by a factor of 3 . As regards native $\alpha$-LA, a separation degree at microfiltration of approximately $29 \%$ and a yield of $7.5 \%$ could be achieved (Fig. 8). The higher yield obtained at the aforementioned process was due to the higher content of native $\alpha$-LA before microfiltration.

The separation degrees of native $\alpha$-LA by microfiltration are related to the used membrane type and the operational parameters as e.g. the transmembrane pressure difference and flow velocity of the retentate. For all the experiments, they were maintained at a constant level. To which extent optimised operational conditions could further increase the separation degree of $\alpha$-LA has yet to be investigated. 


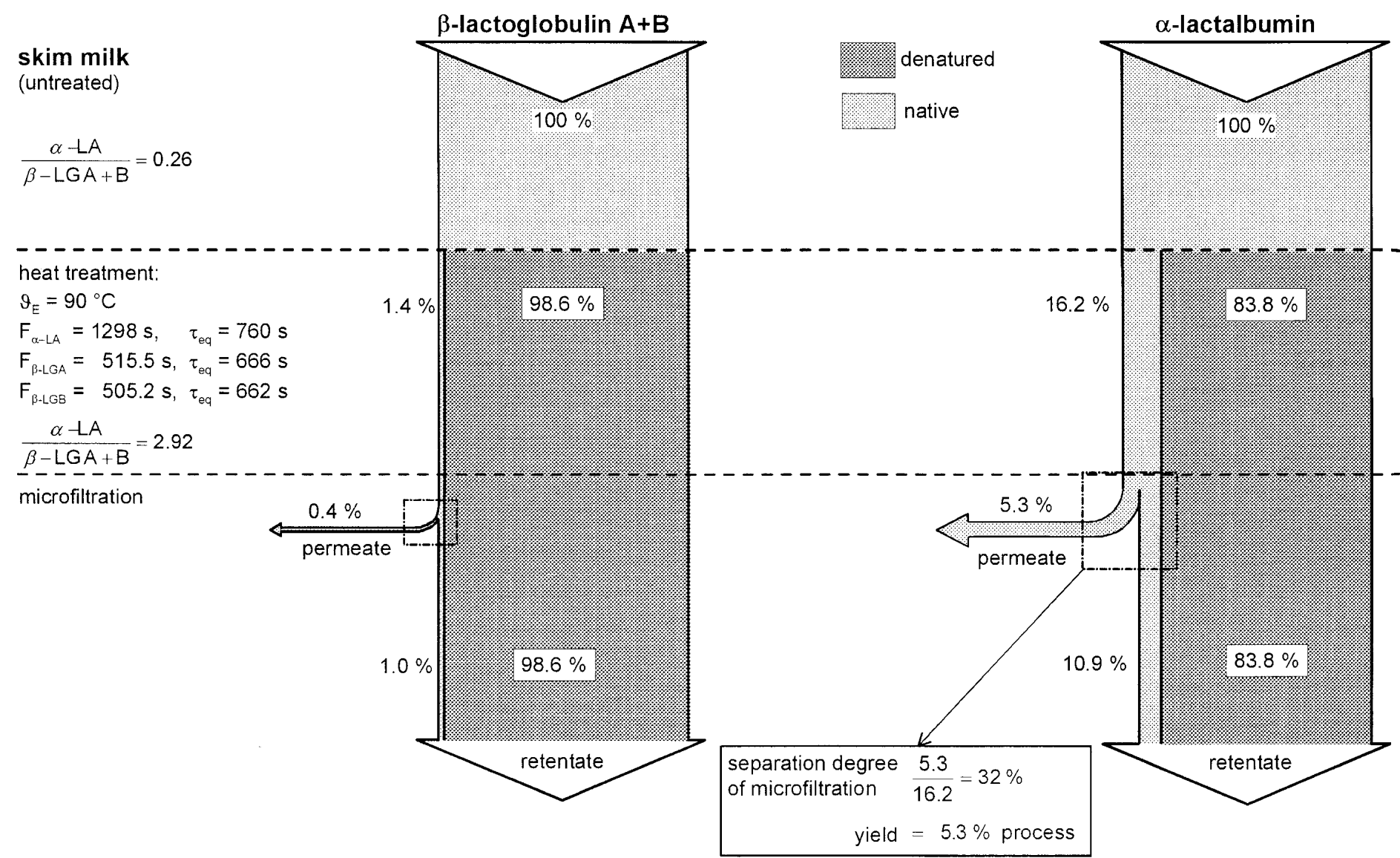

Figure 7. Yield and separation degree of the process as regards native $\alpha$-LA with skim milk as initial product. 


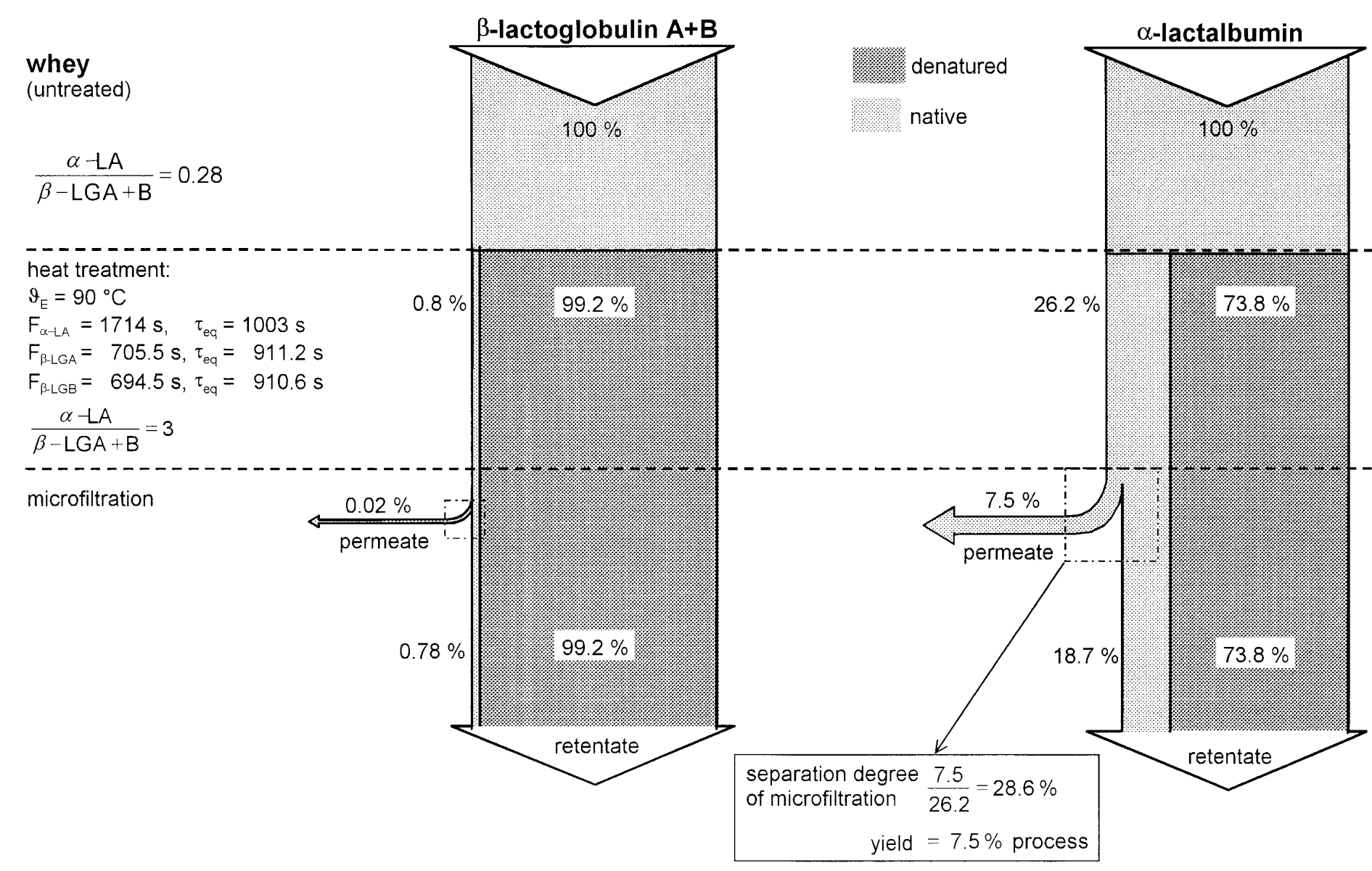

Figure 8. Yield and separation degree of the process as regards native $\alpha$-LA with whey as initial product. 
Because $\alpha$-LA exhibits a much higher relative tryptophan content as compared to $\beta$-LG (280 $\mathrm{nmol} \cdot \mathrm{mg}^{-1}$ for $\alpha$-LA as compared to $110 \mathrm{nmol} \cdot \mathrm{mg}^{-1}$ for $\beta-\mathrm{LG}$ ) this parameter is suited for assessing modified composition of whey systems. Using sweet whey as initial product, a tryptophan content in the MF permeate of $170 \mathrm{nmol} \cdot \mathrm{mg}^{-1}$ protein was detected, thus being by a factor 1.7 higher than in whey. At using skim milk as initial product a tryptophan content of $181 \mathrm{nmol} \cdot \mathrm{mg}^{-1}$ protein was detected and was by a factor 1.8 higher than in whey, Figure 9.

\section{CONCLUSION}

A selective denaturation of $\alpha$-LA and $\beta-\mathrm{LG} A+\mathrm{B}$ can be performed by means of a defined thermal treatment. The ratio of native $\alpha$-LA / $(\beta$-LGA $+\beta$-LGB) can be increased in relation to the initial products (skim milk or whey). The reaction kinetics of the denaturation of whey proteins allow to compute in advance the real temperaturetime-curves of a heat treatment including of heating-up and cooling phases. After heat treatment and subsequent microfiltration, the then analytically detected contents of whey proteins in permeate and retentate reveal that a separation of native portions, especially of $\alpha$-LA from the denatured portions, is possible. With the selected operational parameters and at using sweet whey or skim milk as initial products, a separation degree of microfiltration of approximately $30 \%$ and a yield of approximately $6 \%$ as regards the initial content of $\alpha$-LA can be achieved. Simultaneously, the enrichment of $\alpha$-LA can be demonstrated via the increase of the tryptophan content in the MF permeate. The yield of the described method is relatively low but on the other hand the technical input is rather simple. A further optimization of the separation degree by modifying the operational parameters of microfiltration should be aimed at. Because of the rather low protein content of the MF permeates, only subsequent ultrafiltration will result in systems being possibly applicable in dietetics. Because the separation process described here involves stronger heating of milk or whey it has to be examined to which degree the final structure of $\alpha$-LA is still native or modified, i.e. in the so-called molten globule state which may not be optimal when using bovine $\alpha$-LA in infant formulas [3]. Whether this process has any chance for an industrial scaling up remains to be examined. However, the

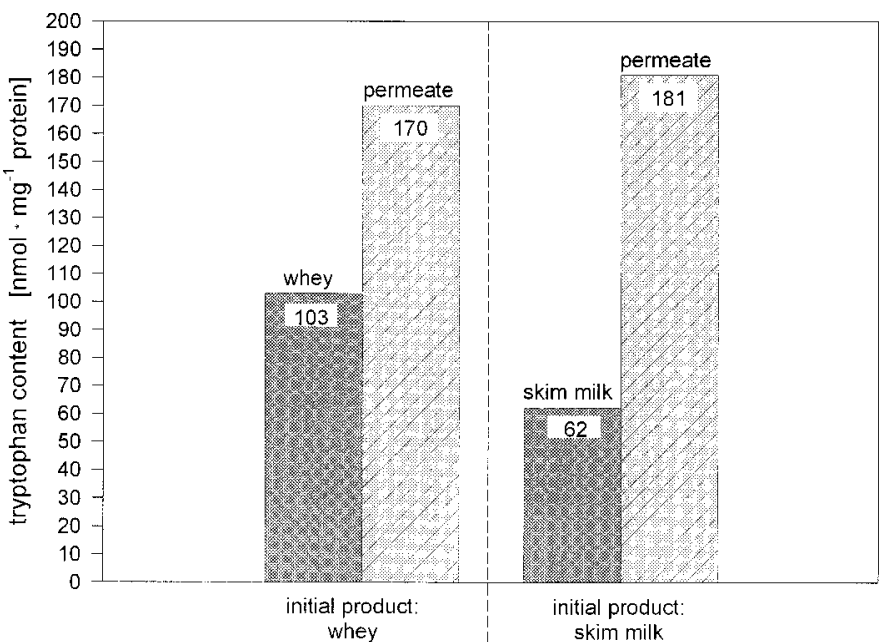

Figure 9. Comparison of tryptophan contents in initial products and permeates. 
further use of the large amount of MF retentate, at least if milk was processed, should be possible e.g. in yoghurt manufacture.

\section{REFERENCES}

[1] Amundson C.H., Watanawanichakorn S., Hill G.G.Jr., Production of enriched protein fractions of $\beta$-lactoglobulin and $\alpha$-lactalbumin from cheese whey, J. Food Process Preserv. 6 (2) (1982) 55-71.

[2] Biewendt H.-G., Die Bedeutung von Sterilisationswerten für das Ultrahocherhitzen von Milch (Meaning of sterilisation-values in the ultrahight-heating of milk), Die Nahrung 38 (1994) 233-252.

[3] Chatterton D.E.W., Nielsen K.E., Holst H.H., Bartelsen H., Albertsen K., $\alpha$-Lactalbumin - A protein ingredient for use in infant nutrition, in: Werner H. (Ed.), Proceedings of the 25th International Dairy Congress, Part II Dairy Science and Technology, The Danish National Committee of IDF, Aarhus, Denmark, 1999. pp. 402-409.

[4] Dannenberg F., Zur Reaktionskinetik der Molkenprotein-denaturierung und deren technologischer Bedeutung (Reaction kinetics of whey protein denaturation and their technological signification), Ph.D. thesis, Technical University München, Germany, 1986.

[5] German Industrial Standard (DIN 10473): Bestimmung des Gehaltes an säurelöslichen $\beta$-Lactoglobulin in hitzebehandelter Milch (Determi- nation of acid soluble $\beta$-lactoglobulin in heat treated milk).

[6] Heine W., Radke M., Wietzke K.D., Polars E., Kundt G., $\alpha$-lactalbumin-enriched low-protein infant formulas: a comparison to breast milk feeding, Acta Pediatr. 85 (1996) 1024-1028.

[7] Kaneko T., Wu B.T., Nakai S., Selective concentration of bovine immunoglobulins and $\alpha$-lactalbumin from acid whey using $\mathrm{FeCl}_{3}$, J. Food Sci. 50 (1985) 1531-1536.

[8] Kuwata T., Pham A.M., Ma C.Y., Nakai S., Elimination of $\beta$-lactoglobulin from whey to simulate human milk protein, J. Food Sci. 50 (1985) 605-609.

[9] Mailliart P., Ribadeau-Dumas B., Preparation of $\beta$-lactoglobulin and $\beta$-lactoglobulin-free proteins from whey retentate by $\mathrm{NaCl}$ salting out at low pH, J. Food Sci. 53 (1988) 743-745.

[10] Maubois J.L., Pierre A., Fauquant J., Piot M., Industrial fractionation of main whey proteins, Bulletin of the IDF No 212 (1987) 154-159.

[11] Meisel H., Application of fourth derivative spectroscopy to quantitation of whey protein and casein in total milk protein, Milchwissenschaft 50 (1995) 247-251.

[12] Pearce R.J., Thermal separation of $\beta$-lactoglobulin and $\alpha$-lactalbumin in bovine cheddar cheese whey, Austr. J. Dairy Technol. 38 (1983) 144-149.

[13] Tossavainen O., Rantamäki P., Outinen M., Tupasela T., Koskela P., Functional properties of the whey protein fractions produced in pilot scale processes, Milchwissenschaft 53 (1998) 453-458. 